\title{
ENVIRONMENTAL RISK MANAGEMENT OF FUEL COMPANIES IN THE FINANCIAL STATEMENTS
}

\author{
ADAM LULEK \\ University of Szczecin, Faculty of Management and Economics of Services, POLAND \\ e-mail: adam-Iulek@wp.pl
}

RECEIVED
ACCEPTED
JEL
CLASSIFICATION

KEYWORDS financial statements, fuel companies, risk management

ABSTRACT The word risk has been with us for centuries. Over time, it has evolved and today we can talk about different types of risks, including environmental risk. Listed companies, in particular fuel ones, through their operations affect the surrounding nature. Therefore, they should inform customers, shareholders, investors of their doings. The best way to do this is an appropriate presentation of information on risk management in the enterprise. Unfortunately, the present state of affairs is not ideal. Data presented in reports that relates to the said aspect is incomplete, poorly illustrated and unreadable. In their presentation of risk management, companies should take account of its stages. Stakeholders should be able to read about the identification, assessment, essence, description, financing and administration of environmental risk. All this information should be presented in a coherent, easy-to-find and clear manner. As a result, shareholders or investors will be able to make better investment decisions concerning a given company.

\section{Introduction}

The proper functioning of economy, including financial and capital markets, should ensure the financial stability of a business entity Sadowska (2010, p. 76) and determine the minimization of risk of business activities, especially environmental risk. Environmental risk is characteristic of many production enterprises. It concerns in particular fuel, 
energy and chemical companies. Their activities are connected with landfill, hazards during operational activities and other fortuitous events which a management board is not always able to predict.

In financial statements, listed companies often describe various types of risk. One of them is environmental risk. Depending on what an entity deals with exactly, they can concern different situations, entities or subjects. However, in order to reduce this aspect of business activities, entities should manage environmental risk properly. How do they do that? This is something we learn from financial statements which are the main source of such information. What do companies exactly describe and is this data sufficient for interested parties?

\section{Environmental risk}

The term risk can be already find in the Middle Ages as riscum, that is expeditions and natural disasters. Over time, the term was subject to modifications. In the 16th century in banking risiko, that is rational human activities, emerged. A hundred years later, British money dealers started to use the word risk when searching for regularities governing fate of fortune. No until the 19th century, strokes of fate, destiny or fortune were replaced by assessing the likelihood of desirable or undesirable events Solarz (2005, pp. 15-16).

Currently, risk means negative (sometimes also positive) deviations from intended goals. Every enterprise's business activity is exposed to risk. It stems from the fact that enterprises operate in an environment which is changeable and unpredictable. It accompanies all decisions which are made Buk (2006 p. 374). In other words, "risk means such a situation in which future events cannot be predicted with certainty, however, the probability of distribution of these events is known" Czekaj, Dresler (2001, p. 35). In literature, we deal with various types of risk and one of them is environmental risk Holliwell (2001, p. 5).

It can be defined as a possible impact of enterprise's operations on the natural environment which constitutes an element of enterprises' sustainable development ${ }^{1}$ Sadowska (2016, p. 396). Obviously, this statement was written with a negative aspect in view as it concerns ecological degradation. When undertaking business activities, many companies expose nature to irreversible changes. They can be caused by: ${ }^{2}$

- improper resource management,

- fortuitous events,

- lack of responsibility and awareness of the management,

- unskilled employees,

- specific character of given business activities,

- lack of environmental rules and procedures in an enterprise.

The influence of the aforementioned factors on the environment can be reduced through proper risk management in a given business entity. Information concerning the above statement is not always clear in listed companies. Interested parties would like to know what risk occurs in an enterprise and how it is managed.

${ }^{1}$ It is postulated that enterprises should run business activities on the basis of the balance between economic, social and ecological goals and have respect for the natural environment in mind. More: B. Sadowska (2016), p. 396.

2 The author's own conclusions. 


\section{Environmental pisk management}

According to the ISO 31000:2009 standard and the Polish PN-ISO 31000:2012 standard, risk management means coordinating activities concerning management and supervision of an organization with regard to risk.

This process comprises several stages:

1. Risk identification - a fundamental element of the risk management process. It involves searching for risk effects.

2. Risk quantification - a description of risk, what risk means, its causes and effects.

3. Risk assessment - stipulating risk potential resulting from enterprise's activities and external influences.

4. Risk reaction - conscious risk modification.

5. Risk administration - risk is attributed to a relevant person or people on the basis of an enterprise's structure.

6. Risk financing - securing funds for risk avoidance, control, transfer or retention (Szczepankowski, 2006, pp. 255-256).

Therefore, it can be assumed that environmental risk management means coordinated activities aimed at reducing or eliminating a negative impact of enterprise's activities on the natural environment. ${ }^{3}$ However, is it possible to distinguish particular stages of this process in enterprises? Is data included in financial statements and concerning the discussed issue properly presented? Can interested parties receive a proper amount and quality of information on that issue? In order to answer these questions, one should analyse Table 1.

Table 1. Investors' risk connected with environmental information published in periodic reports by listed companies

\begin{tabular}{|c|c|c|c|}
\hline $\begin{array}{l}\text { ટે } \\
\text { ठั } \\
\text { हે } \\
\text { ठ }\end{array}$ & $\begin{array}{l}\text { Type of financial } \\
\text { statements }\end{array}$ & $\begin{array}{l}\text { Environmental risk connected with the functioning } \\
\text { of companies and significant for stock investors }\end{array}$ & Risk management \\
\hline 1 & 2 & 3 & 4 \\
\hline 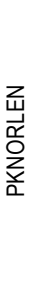 & $\begin{array}{l}\text { Report on the operations } \\
\text { of PKN ORLEN } \\
\text { for the year 2012, annual } \\
\text { report for the year } 2012\end{array}$ & $\begin{array}{l}\text { - risk connected with the launch of biofuels, } \\
\text { - risk connected with carbon dioxide emission, } \\
\text { - risk connected with conducting operations (random } \\
\text { loss) }\end{array}$ & $\begin{array}{l}\text { The Capital Group creates provisions for future } \\
\text { liabilities due to reclamation of contaminated land } \\
\text { or water or elimination of harmful substances if there } \\
\text { is such a legal or constructive obligation. Environmental } \\
\text { provision for reclamation is periodically reviewed } \\
\text { based on reports prepared by independent experts. } \\
\text { The Capital Group conducts regular reclamation } \\
\text { of contaminated land that decreases the provision } \\
\text { by its utilization }\end{array}$ \\
\hline$\underset{\substack{0 \\
\hdashline}}{\sum_{0}}$ & $\begin{array}{l}\text { Report } \\
\text { of the Management } \\
\text { on the operations } \\
\text { of the PGNiG Capital } \\
\text { Group for the year } \\
2011 \text {, annual report } \\
\text { for the year } 2011\end{array}$ & $\begin{array}{l}\text { - the need to ensure compliance with environmental laws } \\
\text { in Poland and abroad may significantly increase the } \\
\text { PGNiG Group's operating expenses, } \\
\text { - significant capital expenditure and costs on ensuring } \\
\text { compliance of its operations with the even more } \\
\text { complex and stringent regulations concerning safety } \\
\text { and health } \\
\text { at work, as well as environmental protection, } \\
\text { - hydrocarbon deposits developed by the PGNiG Group } \\
\text { are often at great depths, consequently, the risk } \\
\text { of hydrocarbon blowout or leakage is very high, which } \\
\text { in turn may pose a threat to people (workers and local } \\
\text { populations), the natural environment and production } \\
\text { equipment }\end{array}$ & $\begin{array}{l}\text { To date, more than three-quarters of the PGNiG } \\
\text { Branches and the PGNiG Group key companies have } \\
\text { implemented, certificated and had in place } \\
\text { the Environmental Management System (EMS), } \\
\text { frequently integrated with other systems, such } \\
\text { as quality, OHS or information security management } \\
\text { systems. In 2011, another two gas companies } \\
\text { completed the implementation of the Environmental } \\
\text { Management System. Also in 2011, the identification } \\
\text { methods and assessment criteria for environmental } \\
\text { aspects of the operations were standardised for gas } \\
\text { companies }\end{array}$ \\
\hline
\end{tabular}

3 The article author's own definition. 
12
The refinery uses technologies and equipment meeting the BAT criteria (Best Available Techniques). Process units are equipped with adequate safety and security solutions. Alarm, emergency stop and shutdown systems are deployed in order to prevent uncontrolled development of an emergency situation and serious damage to machinery and equipment.

All measures for prevention of fires, failures and similar incidents also aim to minimize possible environmental impact. We have also adopted safety standards in sea transport which help mitigate various risks, including the risk of an environmental disaster caused by tankers leaking oil or petroleum products. We have established relationships with providers of sea shipping services operating fleets that meet high technical requirements and properly observe maritime safety conventions. We use the services of ship owners who satisfy very strict requirements on the mitigation of the risk of maritime accidents

The Company is engaged in relatively high risk activities. The Company is committed to both safety in operations and to preserving and protecting the environment. The Company believes it fully complies with or exceeds all government regulations and industry standards in the countries of operation. However, operations are subject to regulation and intervention by governments that can affect exploration, production and abandonment of fields and licenses. Rights and licenses can be cancelled, may expire or be expropriated, and regulations can change. Certain licenses have restrictions which may not be removed on a timely basis. Certain areas in which the Company operates are politically and economically unstable and the assets and operations may be affected by changes in government policy, social instability or other political or economic developments outside the control of the Company. Contingency plans are in place to ensure a timely response to a safety or environmental event. A security program is also in place to protect the Company's assets and staff

In 2012, we had a comprehensive review of risk in order to check whether we are well-prepared to prevent and react properly to emerging, both expected and unexpected challenges. This review was very useful and constitutes a solid basis for the development of DUON in 2013 and the following years. No details were mentioned

- low risk because of the fact that the company is a gas provider

No specific information on environmental risk management in significant additional liabilities and deterioration of the

Group's development prospects,

of the Issuer's Capital

Group for the year ended

- risk of the introduction of regulations on the reduction

of greenhouse gas emissions annual report

Source: own study on the basis of financial statements of the mentioned companies. 
Table 1 shows information concerning environmental risk included in annual reports and financial statements on operations of companies from WIG-Paliwa (Fuels) sector and data referring directly to the management of such risk. What results from the information in the table is that in fuel companies' documents we can most often read about risk connected with:

- raw materials and fuels,

- investments in fixed assets connected with the natural environment,

- improvement of effectiveness and production quality, what has an influence on the environment,

- adaptation to applicable standards and provisions of law,

- training for employees in order to raise their ecological awareness.

The aforementioned information has an influence on risk of fuel companies' operations which, in their case, is high with respect to the natural environment. Most often, this risk pertains to toughening national and EU regulations related to the natural environment and possible pollution as a result of fortuitous events.

After analysing data connected with risk management, it can be assumed that not all enterprises provide specific information in this respect. On a case-by-case basis, it is difficult to find data concerning the analysed issue, what is unacceptable in such companies. Some of them provide selective information. The management board tries to manage risk, however, the way they do is not included in reports. The vast majority of entities give limited information on the aforementioned process. Most often, one can learn about the allocation of relevant investment funds, application of relevant standards or regulations, creation of reserves for potential events and implementation of modern technologies.

\section{Method}

During writing the article, the methods of inductive and deductive reasoning as well as descriptive analysis were used. The research process involved the identification of a research problem, that is the problem of environmental risk insufficiently described in financial statements. The next research stage was about commenting on the phenomenon by analysing environmental information included in financial statements of fuel companies which have been listed in a table. The study shows the current state of the presentation of environmental risk and its management stages by selected listed companies in reports. On the basis of the above, conclusions were drawn. The author tried to assess and show how information on environmental risk management should be presented in financial statements. In order to devise own concept, financial statements and risk management stages presented in the environmental realities were analysed.

\section{Results}

As it was mentioned in the previous subchapter, listed companies provide insufficient information on environmental risk management in fuel companies. Investors are not able to answer any of the posed questions. Currently, in reports:

- information on risk management divided into stages cannot be found,

- the way to minimize environmental risk is not sufficiently indicated,

- data concerning the issue is often presented in a chaotic way and it is spread across several dozen pages,

- there is a mediocre amount and quality of information in terms of the issue,

- data is insufficient for stock investors to make decisions on the purchase or sale of securities. 
On the basis of the given division of risk management, details of this process can be provided for fuel companies. Table 2 presents the author's proposal.

Table 2. Risk management stages in fuel companies

\begin{tabular}{|c|c|c|c|}
\hline Stage & Specification & Presentation in fuel companies - how it is now & How it should be \\
\hline Risk identification & $\begin{array}{l}\text { A fundamental element } \\
\text { of the risk management } \\
\text { process. It involves } \\
\text { searching for risk } \\
\text { effects }\end{array}$ & $\begin{array}{l}\text { Fuel companies do not have much difficulty } \\
\text { in distinguishing the first stage. Financial } \\
\text { statements of enterprises include quite detailed } \\
\text { information on this issue. Depending on what } \\
\text { a company does exactly, this data can vary } \\
\text { respectively, however, it is still available }\end{array}$ & $\begin{array}{l}\text { Nevertheless, there is a problem with presenting } \\
\text { the aforementioned data. A report could have } \\
\text { a separate section only devoted to risk and its } \\
\text { management }\end{array}$ \\
\hline Risk quantification & $\begin{array}{l}\text { A description of risk, } \\
\text { what risk means, } \\
\text { its causes and effects }\end{array}$ & $\begin{array}{l}\text { Indicating risk is at a satisfactory level, whereas } \\
\text { a detailed description is not. It is difficult to find } \\
\text { data on risk causes or possible effects in reports. } \\
\text { This data is often "scattered" over the whole } \\
\text { financial statements and, as a result, their users } \\
\text { lose valuable time when making decisions }\end{array}$ & $\begin{array}{l}\text { Companies should provide comprehensive } \\
\text { information on causes and effects of a given } \\
\text { risk in their reports. Users of data from financial } \\
\text { statements have the right to know what failure to take } \\
\text { proper precautions can result in }\end{array}$ \\
\hline Risk assessment & $\begin{array}{l}\text { Stipulating risk } \\
\text { potential resulting } \\
\text { from enterprise's } \\
\text { activities and external } \\
\text { influences }\end{array}$ & $\begin{array}{l}\text { The next problem is the lack of information } \\
\text { on the extent of possible risks. Interested parties } \\
\text { do not know where, e.g. production, transport } \\
\text { or storage of crude oil can lead to. Companies } \\
\text { do not mention risk potential, and it should be } \\
\text { changed }\end{array}$ & $\begin{array}{l}\text { Companies should describe comprehensively } \\
\text { and assess the potential of a given risk as well } \\
\text { as possible ways to eliminate it. Interested parties } \\
\text { have to be aware of what environmental problems } \\
\text { a company deals with and what it does to prevent } \\
\text { them. They should also have a possibility of reading } \\
\text { information on the scale of risk which should be fixed } \\
\text { and described }\end{array}$ \\
\hline Risk reaction & $\begin{array}{l}\text { Conscious risk } \\
\text { modification }\end{array}$ & $\begin{array}{l}\text { In some reports, it can be observed that } \\
\text { enterprises try to reduce risk through } \\
\text { the introduction of relevant quality standards. } \\
\text { However, this information is not clear and } \\
\text { complete enough }\end{array}$ & $\begin{array}{l}\text { Companies should provide in-depth data on what } \\
\text { exactly has been done in order to reduce risk. Thanks } \\
\text { to reports, interested parties should have a possibility } \\
\text { of verifying what a company would do, if a given risk } \\
\text { occurred }\end{array}$ \\
\hline Risk administration & $\begin{array}{l}\text { Risk is attributed } \\
\text { to a relevant person } \\
\text { or people on the basis } \\
\text { of an enterprise's } \\
\text { structure }\end{array}$ & $\begin{array}{l}\text { Practically nothing is known about this stage. } \\
\text { In financial statements, there is no information } \\
\text { on who is responsible for risk stemming from } \\
\text { enterprise's operations }\end{array}$ & $\begin{array}{l}\text { Interested parties should be aware of the fact } \\
\text { that it is not only the management board that } \\
\text { is responsible for a company, but also lower-level } \\
\text { employees, e.g. managers, executives. Reports } \\
\text { should include their data }\end{array}$ \\
\hline Risk financing & $\begin{array}{l}\text { Securing funds for risk } \\
\text { avoidance, control, } \\
\text { transfer or retention }\end{array}$ & $\begin{array}{l}\text { In fact, some companies secure some funds in } \\
\text { case of potential unexpected events. However, } \\
\text { it is not also described in detail and does not } \\
\text { pertains to all companies }\end{array}$ & $\begin{array}{l}\text { Companies should precisely indicate what funds have } \\
\text { been allocated to risk occurrence or transfer }\end{array}$ \\
\hline
\end{tabular}

Source: own work.

\section{Conclusions}

If fuel companies, which are particularly exposed to risk resulting from the impact on the natural environment, presented information of risk management in the way suggested in Table 2:

- interested parties would know the process of risk management in a company divided into stages,

- the scale of risk and the value of funds allocated to reduce it could be assessed,

- users of financial statements would receive a great amount of qualitative information which they could use to make investment decisions,

- data concerning environmental risk would be presented in a coherent, easy-to-find and clear manner. 


\section{References}

Buk, H. (2006). Nowoczesne zarządzanie finansami. Planowanie i kontrola. Warszawa: Wydawnictwo C.H. Beck.

Czekaj, J., Dresler, Z. (2001). Zarządzanie finansami przedsiębiorstw. Podstawy teorii. Warszawa: Wydawnictwo Naukowe PWN.

Holliwell, J. (2001). The financial risk manual: A systematic guide to identifying and managing financial risk. Warszawa: Wydawnictwo K.E. LIBER.

Sadowska, B. (2010). Kryzys finansowy głównym problemem ekonomicznym. Zeszyty Naukowe Uniwersytetu Szczecińskiego, 607.

Sadowska, B. (2016). Strategia Państwowego Gospodarstwa Leśnego Lasy Państwowe a zrównoważony rozwój. Research Papers of Wrocław University of Economics, 437.

Solarz, J.K. (2005). Zarządzanie ryzykiem systemu finansowego. Warszawa: Wydawnictwo Wyższej Szkoły Ubezpieczeń i Bankowości.

Szczepankowski, P. (2006). Problemy zarządzania finansami we współczesnych przedsiębiorstwach. Warszawa: University of Finance and Management in Warsaw.

Cite this anticle aS: Lulek, A. (2018). Environmental risk management of fuel companies in the financial statements. European Journal of Service Management, 3 (27/1), 143-149. DOI: 10.18276/ejsm.2018.27/1-17. 